\title{
Impact of Industrialization in Nigeria
}

\author{
Asst. Prof. Dr. Aliya Z. Isiksal \\ Odoh John Chimezie
}

Faculty of Business \& Economics, The American University, Girne, Turkey

doi: 10.19044/esj.2016.v12n10p328 URL:http://dx.doi.org/10.19044/esj.2016.v12n10p328

\begin{abstract}
The objective of this study is to analyze the relationship between GDP, agriculture (AR), industry (ID) and services sector (SV) in Nigeria. The Johansen co-integration testing approach demonstrates a significant long-run relationship between these three variables. The results reveal that agriculture, industry and services have a significant positive relationship with GDP. The Causality results demonstrate a bidirectional causal relationship between GDP, AR, ID and SV. It is suggested therefore that it is important to develop the agricultural sector to provide the needed support to the industrial and services sectors. Such a strategy can be expected to encourage the development and economic growth of a developing country.
\end{abstract}

Keywords: Industrialization, Phillips-Perron unit root test, Granger Causality test

\section{Introduction}

The promotion of industrial development became a major challenge to the African continent during the1960s as the majority of African countries gained their independence at this time. The respective governments saw industrial development as a means for the continent to gain self-reliance and lower their dependence on the industrialized economies. The ideology and beliefs of Africa were based on the vision that industrialization would transform the African economies from traditional agrarian - to progressive and industrialized - based economies. Industrialization was perceived as an instrument of economic growth that will assist the continent to attain its macroeconomic objectives (high income, improved standard of living, selfreliance, job creation and balance of payment stability).

Nigeria presents an example of a developing economy. The bulk of the gross domestic product is from the primary sector with agriculture carrying the greatest share. The oil and gas sector is a major player in the economy and contributes about 95\% to the country's export earnings. 
Compared to the industrial sector which only accounts for small portion (about 6\%) of the economic activity. The manufacturing sector accounts for $4 \%$ of the GDP. The Nigerian economy started experiencing serious difficulty in furthering its industrial development following the discovery of oil in the late 1960s. These difficulties can be attributed to: a weak raw material base (more attention was channeled into mining), inadequate technical manpower, poor policy implementation, poor entrepreneurship, political instability, corrupt government institutions and poor technical know-how (Chete, et al. 2014).

Industrial policy can be an important and powerful instrument for stimulating rapid economic growth and development. Nigeria, however, has failed to make substantial and significant progress and advancement due to weak policies and poor implementation. From the inception of the Nigeria's independence, various governments have been trying a range of approaches centered on the orders of those in power and their advisors. The outcome of these policies has been a huge failure and unpredictably, favoring "rent seeking” (Mike, 2012).

Policy failure can be experienced at two different levels; the first is associated with the formation of policies that fail to achieve optimization, or recognize the real problems and their solutions. Failure can also occur when the policy makers are influenced by vested benefits or external and internal pressures. The second level is associated with implementation. One main defect in industrial policy is the failure to recognize the relevant stakeholders and a policy that is not people centered and inclusive is guaranteed to fail.

In recent times, there has been an improved trend in the industrial policy of the developed economies such as the United States, Britain, France, Germany and Japan, following active government intervention. This new initiative was inspired by four major factors:

i. Pressure to reduce unemployment and stimulate growth, ii. Desire to stabilize some economies away from financial services, iii. Common demands for increased government action, and iv. Perceived need to react to apparently effective policies being pursued in China.

There is a growing consent in development theory that intervention is usually necessary when there is a risk of market failures (Rodrick, 2009). Market failures typically occur in the company of externalities and natural monopolies. These market failures prevent the emergence of an efficient market and effective industrial policies which are required to ensure efficient allocation within a free market. While the recent debate has not reduced the importance of industrial policy, the major argument now concerns achieving the best means of promoting effective industrial policy. 


\section{Literature Review}

Chenery (1960) suggested a stable arrangement of industrial sector improvement. He believed that, as industrial sector development continues, changes are generally noticed in economic structures. An increase in the relative importance of the industrial sector leads to changes in the production methods and sources of supply for industrial produces.

Tamuno and Edoumiekumo (2012) determined production functions using constant substitution of electricity to the Nigerian industrial sector which was centered on a study of the industrial sector from 1962-1975 and discovered that labor and capital have a positive relationship and are also of economic and political importance. They also found that the substitution level in the Nigerian industrial sector is very low.

Globalization can also be shown to be of great importance to the modern process of industrialization of many countries in recent times. Looking at Nigeria, globalization can play a major role in the privatization and commercialization of industries which simply means the transfer of government ownership to private ownership. Such ownership could be full (privatization) or partial (commercialization) (FRN, 1988). That is to say, that the government role is limited to that of maintaining basic law and order. The policies of 1989 were, in the main, accepted as a replacement for the earlier indigenization policies of 1977 that promoted international investments and gave room for local businesses to gain from the National Economic Reconstruction Fund (NERF). Nevertheless, the careful reevaluation of the many published papers on the effects of globalization remains of importance.

Akinbola (2001) believes that the method of globalization which involves the increment of resources and market forces into an unregulated environment results in an unfavorable socio-economic situation for the common people. Using Nigeria as an example, the acceptance of the World Trade Organization (WTO) treaty seriously neglected the fall in the standard of living of the people and aggravated the failure in important sectors of the economy. Structural failure reduced the opportunities for increasing capacity utilization.

Clunies-Ross et al., (2010) state that the industrial growth, or basically industrialization, has two different meanings. It can be perceived as a change in a country's form of production and work force towards producing or minor industries. Relating it to income levels attaining certain level. On this basis nations can be grouped into different income levels (high-income, higher upper income, lower upper income, higher middle income, lowers middle income and the low income countries). This is a larger element of industrialization. 
There are works relating to industrial development and economic growth. Blomstrom et al., (1994) suggest that industrial development through foreign investors can have a positive influence on economic growth level. They claimed that the industrial development contribution to economic growth level is dependent upon a critical minimum level of income. Below this level the contribution of industries to economic growth is insignificant and above this level, it is significant. The reason given is that, countries that have attained certain level of income are those that can benefit efficiently from the experience of those overseas industries and foreign stakeholders with which they come in contact. The benefits include managerial skills, human capital improvement and new technologies.

Shafaeddin (2005) evaluates the economic performance of unindustrialized countries that have commenced economic transformations since the early 80s with the motive of increasing exports and broadening their industrialized sector. The findings obtained were significantly different to those of Clunies et al. Forty percent of the model economies achieved a very rapid improvement in the export of produced goods. For some of the sample economies, mainly those from Eastern Asia, speedy export growth was also followed by a rapid increase of industrial supply capability.

However, the performance of most of the sample economies, mainly those from Latin America and Africa is unsatisfactory. Half of the sample economies suffered poor industrialization. Poor export growth and poor industrialization was followed by a weakening of the economy, mostly the industrial sector, to external influences mainly as far as depending on imports is concerned. Most industries that had been successful during the import substitution period survived. Although, to be successful in production there had to be active exports and high investment.

The import replacing industrial development approach which became popular due to Hirschman's (1958) - 'unstable growth principle' has been often been directed to focus on the most well-known - but nevertheless wrong industries so that, many developing economies did not simply continue to be unstable but became unstable in in the wrong way due supporting just those sectors having the highest comparative disadvantage.

Schilovsky (1987) stresses that this has given import substitution a poor reputation causing many economies to accept export supported growth which is also unstable but it supports industries with high comparative advantage.

Banmijoko (2001) states that the industrial sector in Nigeria is in crisis as its normal contribution to the nation's Gross Domestic Product over the years has not gone above five percent. Many years of abandonment and poor administration on the side of the previous military and civilian 
governments together with corruption and indiscriminate policy problems have all collaborated to reduce the industrial sector inactiveness.

In the 1990s, the agricultural sector focused on food self-sufficiency as its objective. The plan included price maintenance and schemes to regenerate the palm oil, cocoa and rubber subsectors. In the industrial sector, the administration supported a policy of domestic sourcing whereby locally sourced raw materials were transformed into finished goods. In 1999, the industries contributed less than 1\% of Gross Domestic Product. Iwayemi (2011) maintained that the significance of the energy sector is that it will encourage high demand and a rise in supply will motivate high income and high living standards.

Adenikinju (2000) made a strong claim supporting the significance of power supply. The inefficient condition of power supply in Nigeria, his claim has made a significant change on the industrial sector of the economy.

This finding verifies the work of (MAN) Manufacturing Association of Nigeria. In that study, MAN specified that the cost of producing power represents about 36 percent of productivity.

Some of the elements that have a poor influence on the industrial sectors are; institutional structure and management tactics, inflation rate, trends and effect of exchange rate management tactics, inadequate or poor infrastructure particularly power supply. These all have a significant effect on growth and development that has led to the economic expansion of other sectors of the economy.

Economic scholars have largely concurred on the linkages between industrialization and economic growth. In history only three economies can boast of deriving great wealth from agriculture alone (New Zealand, Canada and Australia). The change from agriculture to industry has been a repeated scenario in all other developing economies.

Arthur Lewis (1995) in his dual-sector model expresses his view of economic growth and development within the context of the classical framework with its assumption of unlimited labor supply as the driver of economic development. He believes that the classical model is more applicable for the analysis of the less developed economies.

\section{The Lewis Model of Development}

The Lewis model is known for the two sector economy concept (a rural, agricultural and traditional sector and an urban, industrial and capitalist sector). In the agricultural and traditional sector the population is very high in relation to production output and the natural resources available and the (MPL) marginal productivity of labour in the traditional sector is very low or zero. This means that there is unemployment or under-employment. This is seen as a reservoir of labour supply to the industrial sector. This labour can 
be reduced without reducing output. Moreover there are factors that support an adequate supply of labour; high population growth as a result of low mortality and high birth rate, the daughters and wives released from domestic work, and workers from different types of casual jobs and the unemployment created by increasing efficiency. Hence, labour supply will exceed demand. At that juncture, the labour market will be in favour of capitalists, and capitalists can maintain a constant wage. Lewis (1995) believes that the supply of labour is effectively unlimited on the basis that the capitalist can have a reliable supply of labour at the same wage. The level of wages in the industrial sector is determined by that in the rural sector. Because if the wage in the industrial sector is less than that in the rural sector, no peasant will leave the rural sector to find a job in the industrial or urban sector. According to Lewis, the urban wage is about $30 \%$ more than rural wage. This gap is seen necessary to prompt the change from the rural sector to compensate for the higher cost of living in an urban area or the mental cost of transfer. As the marginal product of labour is insignificant or zero, the wages in the rural sector remain unchanged at a subsistence level. Thus, the wages in the urban sector also remains unchanged. Even if it is greater than the earnings in the rural sector because of a little encouragement, it is no more than rural level in urban life. In the industrial sector, labour is engaged to the point where the marginal product is equal to the earnings in order not to decrease the industrial surplus. Since labour supply is greater than demand and the wage remains unchanged at rural level, the level of profits is fully maximized. Profit oriented capitalists are presumed to invest all profits to generate new capital at a maximum level. Then an industrial expansion creates new employment. The capital accumulation becomes greater but the earnings or wage still remain unchanged so that the excess becomes greater. Full investment level and an unlimited supply of labour guarantee that both capital accumulation and employment improve at the maximum level.

As it engages more labour, the industrial sector keeps improving and expanding. This continues until surplus labour reduces. Henceforth, the migration of surplus labour from the rural sector creates an increase of the marginal productivity of labour in the sector. However, before all surplus labour is exhausted, an increment in profit in the rural sector may occur and influence the growth of the industrial sector. Lewis clarifies this in terms of an exchange between the two sectors on the assumption that they are producing and trading different things. Firstly, the change of total population by transfer of labour will prompt the two circumstances stated below:

One is a decrease of without a doubt in the amount of individuals in the rural sector, regardless of the fact that there is surplus labour and aggregate productivity does not increase, the normal creation per head might 
perhaps increase. This increase in profit in this part pushes up the earnings in the industrial sector.

The other circumstance is that as the industrial sector expands in respect to the supply of rural sector, it has to pay the higher cost of the rural or agricultural products. Accordingly, the terms of exchange move against the industrial sector and industrial its benefits are reduced. Furthermore, if an increase in productivity of the agricultural sector occurs, due to innovation or more efficient cultivating methods, it will directly increase the spending per head in this sector, and indirectly, the industrial workers' earnings will rise. The outcome is the diminishment of the industrial surplus and a reduction in the rate of capital aggregation. Lewis, then, expands his model beyond just one country. Utilizing the established structure which accepts that all countries must have surplus labour, he recommends that the industrialist could minimize the brake on capital accumulation by importing labour from, or sending funding to, countries where surplus work is still accessible at a rural wage.

\section{Methodology and Data}

The data used in this study are secondary data obtained from the Central Bank of Nigeria Statistical Bulletin (2012). The following variables were sourced: Gross Domestic Product (GDP) which is the dependent variable, Industry, Agriculture and the Service are the Independent variables. The Service Sector includes the following subsectors: transport, communication, utilities (electricity and water), hotel and restaurant, finance and insurance, real estate and business services; producers of government services (public administration, education and health), community, social and peers services (private non-profit organizations, other Services and broadcasting). For all the variables their natural logarithmic values were used. The data collected are from first quarter of 1997 to the fourth quarter of 2012.

We first applied Phillips-Perron (PP), to determine whether the variables GDP, AR, SV and ID are stationary or not. If they are not stationary they will be converted I(1) in order to avoid the unit root.

PP test presented as:

$$
\Delta W_{t}=a_{0}+a_{1} W_{t-1}+a_{2}\left(t-\frac{T}{2}\right)+\mu_{t}
$$

Where $a_{0}, a_{1}, a_{2}$ are the least-squares regression coefficients. The unit root hypothesis which are tested are $H_{0}: a_{0}=1$ and $H_{0}: a_{1}=1, a_{2}=0$

It is important to define the lag length since the multivariate cointegration analysis that we implement in our research is very sensitive to the lag length selection. Mostly used the lag length selection criteria are based on Akaike Information Criterion (AIC) and Schawartz Bayesian Criterion 
(SBC).

Having completed the tests of stationary we conduct the Johansen cointegration test (1991). Johansen co-integration approach tests if the determined variables have common trends. The economic framework that was used in this research is the Johansen (1992) and Johansen and Juselius (1990) Maximum Likelikood co-integration technique. Both of them are testing the existence of co-integration and the number of co-integrations. The representation of the co-integration test is the following:

$$
Y_{t}=L_{0}+L_{1} \Delta Y_{t-1}+L_{2} \Delta Y_{t-2}+\ldots \ldots . . L_{p-1} \Delta Y_{t-p} \prod Y_{t-p}+\omega_{t}
$$

Where

$$
Y_{t}=(G D P, A R, S V, I D) ;
$$

$Y_{t}=4 \times 1$ vector of variables that are integrated of order 1 [i. e. I(1)]

$L=4 \times 4$ matrix of coefficients; $\Pi=4 \times 4$ matrix of parameters and; $\omega_{t}=$ error term.

In order to define number of co-integrations the likelihood ratio tests were developed by Johansen, which are: Trace test $\left(\lambda_{\text {trace }}\right)$ and maximum eigenvalue test $\left(\lambda_{\max }\right)$.

After completing the Johansen co-integration test we can use the Granger Causality test to determine the direction of the long-run causality between the variables. It was argued by Granger (1986) that if there is a long-run relationship between the variables the direction of at least one way causality can be established. The Johansen approach tests if there is a longrun relationship but it does not show the direction of causality. To find in which direction the variables affect each other, we will implement Granger Causality within the framework of VECM:

$$
\begin{gathered}
\Delta G D P_{t}=C_{0}+\sum_{i=1}^{q} \mathfrak{y}_{i} \Delta G D P_{t-i}+\sum_{i=0}^{r} \jmath_{i} \Delta A R_{t-i}+\sum_{i=0}^{S} \mathfrak{h}_{i} \Delta S V_{t-i}+ \\
\sum_{i=0}^{m} k_{i} \Delta I D_{t-i}+\Phi_{1} E C M_{t-1}+\mu_{2 t}(3)
\end{gathered}
$$

Where:

$\Delta$ is the first difference operator, $\mathfrak{y}, \mathfrak{z}, \mathfrak{h}, k$ are the coefficients on GDP, $\mathrm{AR}, \mathrm{SV}$ and ID; $\omega$ is the error term; $q, r, s, m$ are the optimal lag length selected based on AIC and SBC; $E C M_{t-1}$ is the error correction mechanism which was taken from the long-run relationship; $\Phi$ stands for the speed of adjustment to the long-run equilibrium.

\section{Empirical Results}

The PP test was used to check if the variables are stationary. The order of integration of GDP, Agriculture, Industry and Services variables should not be greater than one. To be stationary it is accepted if all the variables are I(1). The Phillips-Perron approach was used to test the order of integration of the variables. The results are shown in Table 1. It can be seen 
that the values for Economic Growth, Agriculture, Industry and Services are all I(1).

Table 1 Results of Phillips-Perron Test

\begin{tabular}{|l|l|l|l|l|}
\hline Variables & $\mathrm{I}(0)$ & $\mathrm{I}(1)$ & $\mathrm{C} \& \mathrm{~T}$ \\
\cline { 2 - 5 } & $\mathrm{C}$ & $\mathrm{C} \& \mathrm{~T}$ & $\mathrm{C}$ & $-8.69^{* * *}$ \\
\hline GDP & -0.26 & $-3.79^{* *}$ & $-8.77^{* * *}$ & $-8.64^{* * *}$ \\
\hline AR & -0.55 & $-6.28^{* * *}$ & $-8.72^{* * *}$ & $-8.23^{* * *}$ \\
\hline ID & -0.78 & $-3.92^{* *}$ & $-8.20^{* * *}$ & $-11.35^{* * *}$ \\
\hline SV & -0.98 & -1.80 & $-11.13^{* * *}$ & \\
\hline
\end{tabular}

After checking the order of integration the next step is to implement the co-integration test using the Johansen approach. The optimal lag length of 2, was selected on the basis of the Akaike Information Criterion and Schwartz Bayesian Criterion (Table 2). The lag length results were tested for both serial correlation and heteroscedasticity. The presence of neither was found.

Table 2 Lag Order Selection Criteria

\begin{tabular}{lllllll}
\hline \hline Lag & LogL & LR & FPE & AIC & SC & HQ \\
\hline \hline 0 & -3401.496 & NA & $6.02 \mathrm{e}+42$ & 109.8547 & 109.9919 & 109.9086 \\
1 & -3197.062 & 375.8946 & $1.38 \mathrm{e}+40$ & 103.7762 & 104.4624 & 104.0456 \\
2 & -3106.586 & $154.6848^{*}$ & $1.26 \mathrm{e}+39^{*}$ & $101.3737^{*}$ & $102.6088^{*}$ & $101.8587^{*}$ \\
\hline \hline
\end{tabular}

* indicates lag order selected by the criterion (each test at $5 \%$ leve]

The Trace test results present that there is a long-run relationship between GDP, AR, ID and SV. Table 3 presents the cointegration results:

Table 3 Unrestricted Co-integration Rank Test (Trace)

\begin{tabular}{|c|c|c|c|c|}
\hline $\begin{array}{l}\text { Hypothesized } \\
\text { No. of CE(s) }\end{array}$ & Eigenvalue & $\begin{array}{c}\text { Trace } \\
\text { Statistic }\end{array}$ & $\begin{array}{c}0.05 \\
\text { Critical } \\
\text { Value }\end{array}$ & Prob.** \\
\hline None * & 0.460190 & 76.72322 & 47.85613 & 0.0000 \\
\hline At most $1 *$ & 0.287606 & 39.11443 & 29.79707 & 0.0032 \\
\hline At most $2 *$ & 0.245448 & 18.42784 & 15.49471 & 0.0176 \\
\hline At most 3 & 0.020257 & 1.248366 & 3.841466 & 0.2639 \\
\hline
\end{tabular}

* denotes rejection of the hypothesis at the 0.05 level

We have observed that there are at least three co-integrated variables, meaning that they share a common stochastic trend and will grow proportionally. In other words, they move together in the long run, meaning that they have long run relationship. 
The results of Granger Causality test are in Table 4. We observed that there is a bivariate causation between Agriculture and GDP variables. Agriculture variable does Granger Cause GDP variable, and GDP variable does Granger cause Agriculture variable. There is a bivariate causation between Industry variable and GDP variable. Industry variable does Granger Cause GDP variable, and GDP variable does Granger cause Industry variable. There is an univariate causation from GDP variable to Services variable. We observed that GDP variable does Granger cause Services variable; but Services variable does not Granger cause GDP variable.

Table 4 Granger Causality Tests

\begin{tabular}{cccc}
\hline \hline & & \multicolumn{2}{c}{ F- } \\
Null Hypothesis: & Obs & Statistic & Prob. \\
\hline \hline AGRICULTURE does not Granger Cause GDP & 62 & 8.15652 & 0.0008 \\
GDP does not Granger Cause AGRICULTURE & 48.5195 & $5 . E-13$ \\
\hline \hline INDUSTRY does not Granger Cause GDP & 62 & 3.96168 & 0.0245 \\
GDP does not Granger Cause INDUSTRY & & 6.27075 & 0.0035 \\
\hline \hline SERVICES does not Granger Cause GDP & 62 & 2.98784 & 0.0583 \\
GDP does not Granger Cause SERVICES & & 7.03127 & 0.0019 \\
\hline \hline
\end{tabular}

\section{Conclusion}

This article examines industrialization in developing economies with a focus on Nigeria. We used an index of GDP of the Nigerian economy. Agriculture, Industry and Services were used to measure the domestic investments. The Johansen co-integration results indicate a significant positive long-run relationship between GDP, Agriculture, Industry and Services. The results reveal that there is a bivariate causation between GDP Industrial Sector, Agricultural Sector and Services Sector. These results concur with our expectations. It shows that the level of performance of the industrial sector will be determined by the same level of performance of the agricultural sector which will in turn affects the GDP level. In the light of this, we can say that industrialization is influenced by agricultural output. Thus, an increase in the agricultural sector leads to an increase in the industrial sector and services sector. At present the weak performance of the agricultural sector makes it difficult for the industrial sector to be efficient because the industrial sector lacks the resources needed. Thus for Nigeria to achieve industrialization it must first develop a sustainable agricultural sector to support its industrial sector which in the long-run will lead to a sustainable economy. 


\section{References:}

Adenikinju, A. and Olofin S.O., 2000. "Economic Policy and Manufacturing Sector GrowthPerformance in Africa". The Nigerian Journal of Economic and Social Studies, Vol. 42. No. 1

Aknibola, C. A. (2001), International Project on Cocoa Marketing and Trade in Nigeria. Nigeria.

Bakare-Aremu, T. A. Osobase, A. O. 2015. "Effect of Fiscal and Monetary Policies on Industrial Sector Performance- Evidence from Nigeria”. Journal of Economics and Sustainable Development. Vol6(17).

Blomstrom M., Lipsey, R. E., and Zejan, M. 1994. "What explains developing country growth? In W. J. Baumol (Ed.), Convergence of Productivity: Cross-National Studies and Historical Evidence, 9th ed. New York: Oxford University Press, Incorporated.

Central Bank of Nigeria, 2012. [online] Statistical Bulletin.

Chenery H. B., 1960. "Patterns of industrial growth". The American Economic Review, 50(4):Pp. 624- 654

Chete L. N., Adeoti, J. O., Adeyinka, F. M. and Ogundele, O. 2014. "Industrial Development and Growth in Nigeria Lessons and Challenges". Learning to Complete, Working Paper No. 8.

Clunies Ross., M B. 2010. Verse and Prose in Egils Saga Skallagr'mssonar, Creating the Medieval Saga: Versions, Variability and Editorial Interpretations of Old Norse Saga Literature, University Press of Southern Denmark, Odense, Pp. 191-211

Granger, C. W. J. (1986). "Development in the Study of Cointegrated Economic Variables". Oxford Bulletin of Economics and Statistics, 48, Pp. 213-228.

Hirshman, A., 1958. The Strategy of Economics Development. New Haven: Yale University Press.

Iwayemi A. (2011). "Oil and the Macroeconomy: Empirical Evidence from Oil Exporting African Countries”.

Johansen, S., 1991. "Estimation and Hypothesis Testing of Cointegration Vectors in Gaussian Vector Autoregressive Models". Econometrica 59(6).

Johansen, S., 1992. "Determination of Cointegration Rank in the Presence of a Linear Trend". Oxford Bulletin of Economics and Statistics 54(3).

Johansen and Juselius, 1990. "Maximum Likelihood Estimation and Inference

on Cointegration with Applications to the Demand for Money". Oxford Bulletin of Economics and Statistics 52(2).

Lewis, W. (1955). The Theory of Economic Growth. Homewood, III: Irwin. Mike D., 2012. "New Challenges for Industrial Policy in Nigeria”. Universal Journal of Management and Social Sciences Vol. 2(7). 
Tamuno O. and Edoumiekumo S. G. 2012. "Industrialization and Trade Globalization: What Hope for Nigeria?” International Journal of Academic Research in Business and Social Sciences.

Rodrick, D., 2009. Industrial policy: Don’t ask why, ask how. CEFR NBER Harvard Kennedy School, Harvard University.

Shafaeddin M., 2005. Trade Policy at the Crossroads: The Recent Experience of Developing Countries. London, Palgrave MacMillan. 